\title{
STUDY ON KNOWLEDGE OF FAMILY PLANNING AMONG MMARRIED WOIMEN IN REPRODUCTIVE AGE GOUP IN AN URBAN AREA OF NORTHERN KERALA
}

KEY WORDS: Family

planning; knowledge,

sterilization.

\section{Dr Ärya Lokesan Ratnam*

BACKGROUND India is the second most crowded nation in the world. India will become the most populous country in the world in near future if it follows the current growth rate. Family planning is one of the best methods to tackle this problem. The aim of the study is to assess the knowledge of family planning among married women in reproductive age group in an urban area of northern Kerala.

METHODS A community based cross sectional study was conducted in Kandangali, the field practice area coming under Urban Health Training Centre of a tertiary care Centre from June, 2016 -July, 2017.A total of 491 married females in reproductive age group were studied. A semi-structured pre-tested self-administered questionnaire was used to collect information. .Data was analysed using SPSS software.

RESULTS: Out of 491 married females, $98.4 \%, 0.8 \%$ and $0.8 \%$ were Hindus, Muslims and Christians respectively. Majority (57\%) of them belongs to a family size of less than or equal to 4 members. Majority ( $97.4 \%)$ of women had an educational qualification more than high school and most of the study participants $(35.2 \%)$ were graduates. Majority $(71.5 \%)$ of the women were housewives. Most of the study participants have average knowledge (62.3\%) about family planning methods. Still there are misconceptions regarding condom and male sterilization. The main source of information about family planning was from health workers. Majority (95.7\%) of them had heard of condom (95.7 percent) and the least heard method was injectable (10.6\%).

CONCLUSION: Majority of women had average knowledge towards family planning; still there are misconceptions especially about male sterilization and condom. Continuous health education program have to be conducted about family planning methods.

\section{INTRODUCTION}

India is the second most crowded nation in the world. According to census report 2011 , Indian population stands at 1.2 billion.(1) India will become the most populous country in the world in near future if it follows the current growth rate. The population growth can negatively affect the economic growth and it might become extremely difficult to deal with its demographic implications in future. Family planning is one of the best methods to tackle this problem. National family planning method was first launched by India, in the year 1952.(2)

An expert committee (1971) of the WHO gave the definition of family planning as "'the methods/practices that help individuals or couples to attain certain objectives:

- To avoid undesirable births.

- To bring about desirable births.

- To regulate the intervals between pregnancies

- To control the time at which births occur in relation to the ages of the parent; and

- To determine the number of children in the family."(3)

Family planning is also an important measure that ensures safe motherhood. It helps to reduce maternal mortality and morbidity. Effective family planning measure helps in spacing child births thus ensuring better health of both mother and child, especially in case of high risk mothers. When the births are properly spaced, the child is more likely to receive proper care and nutrition, thus thereby reducing child mortality and morbidity. Family planning practices not only benefits mother and children but also the family and indirectly the whole nation.(4)

\section{Family planning in Kerala}

Before 1950's, the awareness regarding family planning practices was low in Kerala, similar to other states in India. The official family planning program in Kerala was introduced only by the mid- fifties. From a level close to zero, the use of family planning methods in Kerala achieved a level of $75 \%$. As elsewhere in India, family planning method followed in Kerala was predominantly tubectomy, as compared to vasectomy, and it still continues to be the most popular method in the state.(5)

The three temporary methods promoted by the government family planning program are: pills, IUDs, and condoms. Knowledge regarding these three modern temporary contraceptive methods in Kerala has decreased by two percentage points from NFHS-2 to NFHS-3. NFHS-3 survey also reported that the percentage of women who knew about male sterilization had fallen from $94 \%$ in NFHS-2 to $74 \%$ in NFHS-3.(6)

The aim of this study is to assess the knowledge of family planning methods among currently married females in reproductive age group in an urban area of Northern Kerala.

\section{MATERIALS \& METHODS}

Study design: Community based cross sectional study.

Study period: June 2016-July 2017

Study setting:In the field area coming under Urban Health Training Centre, of a tertiary care centre.

A community based cross sectional study was conducted in Kandangali, the field practice area coming under Urban Health Training Centre. Kandangali is located under Payyanur Municipality, Kannur district, Kerala. A house to house survey was carried out and all married females aged between 15 to 49 years were included in the present study. Those participants who did not give consent for the study, who underwent hysterectomy, and those who were not there at home at the time of interview were excluded.

\section{Study population:}

All married women of Reproductive age group (15-49 years) living in the field practice area (Kandangali). 


\section{Inclusion Criteria:}

1. Married women in reproductive age group.

\section{Exclusion Criteria:}

1. Women who underwent hysterectomy.

2. Women who were mentally challenged.

3. Women who were widow/separated.

\section{Sampling:}

All married women of Reproductive age group (15-49 years) living in the field practice area were covered.

Tools:

A pre tested self-administered semi-structured questionnaire.

Questionnaire was standardized after conducting a pilot study.

\section{Data collection method}

The study was conducted in the field practice area coming under Urban Health Training Centre. With the help of accredited social health activist (ASHA) workers in the area, a house to house visit was done. Participants were, married women aged between 15 years and 49 years, residing in the field practice area. From those who were willing to participate in the study, written informed consent was obtained. Data were collected using a semi-structured pre-tested selfadministered questionnaire recording socio-demographic background (age, level of education, occupation, religion, family size, age at marriage, number of children, birth interval, and socio economic status) and knowledge on family planning.

Knowledge was assessed by giving scores to different family planning method with maximum total score being 9 and minimum score being zero. Knowledge was graded as poor (0-3), average (4-6) and good (7-9).

\section{Pilot testing:}

Pilot testing was done among twenty reproductive age group women of study population and the required changes were made in the questionnaire.

\section{Socio economic scale:}

In this study, modified B.G Prasad scale (2016) is used to assess the socio economic status (SES).

\section{Statistical Analysis}

The data was entered in Microsoft Excel 2007 spread sheet and analysed using SPSS version 16.0 software.

\section{RESULTS}

The total number of participants in the study was 491 .

Table no.1: Age wise distribution of the study population $(n=491)$

\begin{tabular}{|l|l|l|}
\hline Age group (in years) & Frequency & Percentage \\
\hline $15-19$ & 2 & 0.4 \\
\hline $20-24$ & 30 & 6.1 \\
\hline $25-29$ & 71 & 14.5 \\
\hline $30-34$ & 108 & 22.0 \\
\hline $35-39$ & 110 & 22.4 \\
\hline $40-44$ & 100 & 20.4 \\
\hline $45-49$ & 70 & 14.3 \\
\hline Total & 491 & 100.0 \\
\hline
\end{tabular}

Table no. 1 shows that out of 491 study populations, majority were in the age group $35-39$ years $(22.4 \%)$ and $30-34$ years $(22 \%)$ and the least were in the age group, $15-19$ years $(0.4 \%)$. The mean age of the study participants was $35.93 \pm 7.28$ years.

Table no.2: Religion wise distribution of the study population ( $n=491)$

\begin{tabular}{|l|l|l|}
\hline Religion & Frequency & Percentage \\
\hline
\end{tabular}

\begin{tabular}{|l|l|l|}
\hline Hindu & 483 & 98.4 \\
\hline Muslim & 4 & 0.8 \\
\hline Christian & 4 & 0.8 \\
\hline Total & $\mathbf{4 9 1}$ & $\mathbf{1 0 0 . 0}$ \\
\hline
\end{tabular}

Table no. 2 shows that, out of the 491 married women $98.4 \%$ of the women belong to Hindu religion.

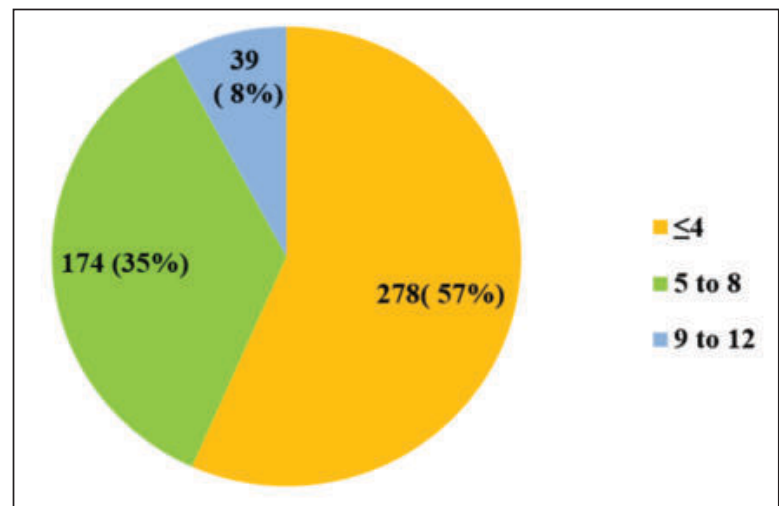

Figure no.1: Distribution by number of family members $(n=491)$

Figure no.1: shows that, $57 \%$ of the total study population belongs to a family size of less than or equal to 4 members and $8 \%$ belongs to a family size of 9 to 12 members.

Table no.3: Socio-demographic factors of the study participants $(n=491)$

\begin{tabular}{|l|l|l|}
\hline Factors & Frequency & Percentage \\
\hline Education & 3 & 0.6 \\
\hline Primary school & 10 & 2.0 \\
\hline Middile school & 126 & 25.7 \\
\hline High school & 148 & 30.1 \\
\hline $\begin{array}{l}\text { Intermediate } \\
\text { school/post diploma }\end{array}$ & 173 & 35.2 \\
\hline Graduate & 31 & 6.3 \\
\hline Profession & 491 & 100 \\
\hline Total & \multicolumn{2}{|l|}{} \\
\hline Occupation & 22 & 4.5 \\
\hline unemployed & 12 & 2.4 \\
\hline unskilled & 30 & 6.1 \\
\hline Semi skilled & 38 & 7.7 \\
\hline skilled & 9 & 1.8 \\
\hline Clerical/shop owner & 19 & 3.9 \\
\hline Semi profession & 351 & 71.5 \\
\hline House wife & 10 & 2.0 \\
\hline Professional & 491 & 100.0 \\
\hline Total & &
\end{tabular}

Table no. 3 shows that, Majority (35.2\%) of the total study population were graduates and $6.3 \%$ had professional qualification. There was no illiterate in study population. Majority (71.5\%) of the study population were housewives.

Table no.4: Distribution according to age at marriage. $(n=491)$

\begin{tabular}{|l|l|l|}
\hline Age At Marraige & Frequency & Percentage \\
\hline$<18$ years & 72 & 14.7 \\
\hline 18 to 26 years & 379 & 77.2 \\
\hline 27 to 35 years & 40 & 8.1 \\
\hline Total & 491 & 100.0 \\
\hline
\end{tabular}

Table no.4 shows that, majority $(77.2 \%)$ of the study population got married between the age group 18 to 26 years. The mean age at marriage of mothers was 21.7 years with a SD of 3.3 years.

Table no.5: Distribution by number of children $(n=491)$

\begin{tabular}{|l|l|l|}
\hline No of children & Frequencey & Percentage (\%) \\
\hline 0 & 31 & 6.3 \\
\hline
\end{tabular}




\begin{tabular}{|l|l|l|}
\hline 1 & 124 & 25.5 \\
\hline 2 & 309 & 62.9 \\
\hline 3 & 25 & 5.1 \\
\hline 4 & 2 & 0.4 \\
\hline Total & 491 & 100.0 \\
\hline
\end{tabular}

Table no.5 shows that majority of the study population $(62.9 \%)$ has two children and $0.4 \%$ has four children.

Fig no 2: Socio-economic status* of the study population $(n=491)$

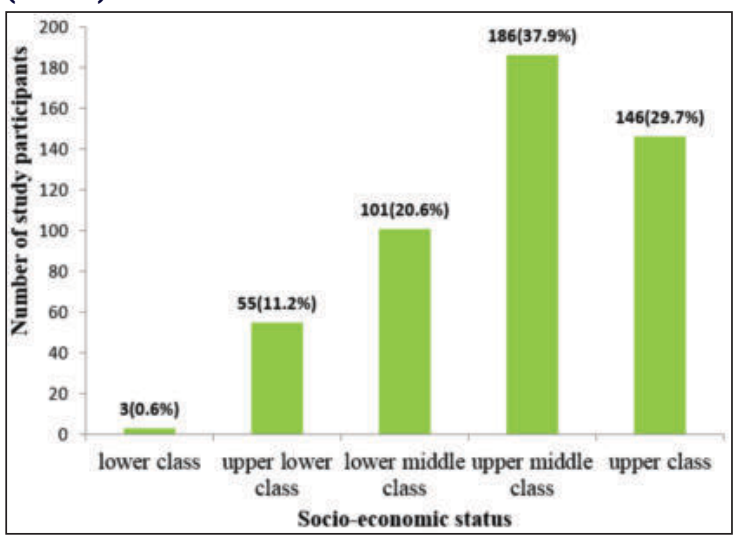

*Updated B G Prasad scale 2016

Fig no: 2 show that majority (37.9\%) of the study participants belongs to upper middle class and $0.6 \%$ belongs to lower class.

\section{Knowledge}

All the study population (100\%) have heard of/ aware of family planning methods

Table 6: Reported sources of information regarding family planning methods

\begin{tabular}{|l|l|l|}
\hline Source of Information & Frequency & Percentage \\
\hline Health worker & 354 & 72.1 \\
\hline Husband & 173 & 35.2 \\
\hline Doctor & 126 & 25.7 \\
\hline Family & 78 & 15.9 \\
\hline Friends & 74 & 15.1 \\
\hline Television & 66 & 13.4 \\
\hline Books & 90 & 18.3 \\
\hline News paper & 48 & 9.8 \\
\hline Radio & 2 & 0.4 \\
\hline Co-workers & 41 & 8.4 \\
\hline
\end{tabular}

Out of the total population, majority $(72.1 \%)$ of them had the source of information about family planning from the health worker. Source of information from husbands and doctors were $35.2 \%$ and $25.7 \%$, respectively. Radio $(0.4 \%)$ was the least mentioned source of information about family planning method.

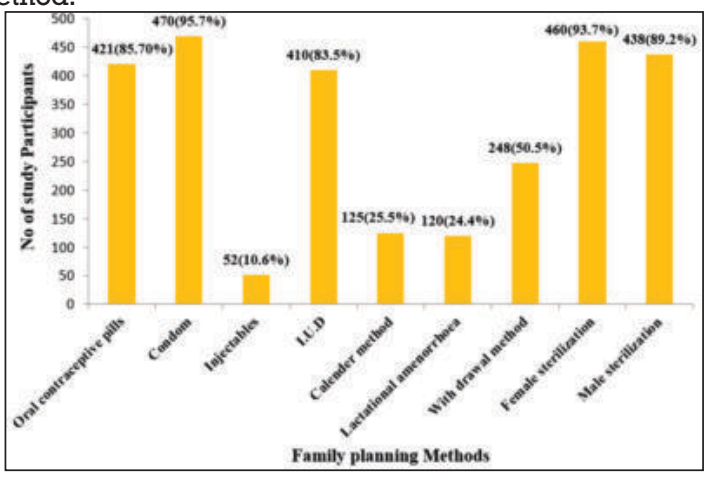

Fig no.3: Types of family planning methods known to study participants

|www.worldwidejournals.com |
Most of them were aware of at least two methods. Awareness of the condom was highest (95.7\%). Awareness of permanent methods (female sterilization and male sterilization) was also quite high (at $93.7 \%$ and $89.2 \%$, respectively). Awareness of natural methods (withdrawal method, lactational amenorrhea, and Calendar method) was at $50.5 \%, 24.4 \%$, and $25.5 \%$, respectively. Among the study participants, injectable $(10.6 \%)$ was the least aware method.

Table no. 7: Awareness about side effects of family planning methods.

\begin{tabular}{|l|l|l|}
\hline Method (n*) & Frequency & Percentage (\%) \\
\hline O.C.P( $\mathrm{n}=421)$ & 137 & 32.5 \\
\hline I.U.D(n=410) & 165 & 40.2 \\
\hline Injectable(n=52) & 8 & 15.4 \\
\hline Male sterilization & 12 & 2.7 \\
\hline Female sterilization(460) & 51 & 11.1 \\
\hline
\end{tabular}

$*_{n}$ is the total no of study participant who have heard about the particular family planning method.

Table no.7: shows that, the awareness about side effects of permanent methods of contraception (male sterilization and female sterilization) were $2.7 \%$ and $11.1 \%$ respectively, while those of temporary methods (I.U.D, O.C.P and Injectable) were $40.2 \%, 32.5 \%$ and $15.4 \%$ respectively.

Table no. 8: Side effects of natural methods as perceived by study participants.

\begin{tabular}{|l|l|l|}
\hline Methods (n*) & Perception & Percentage \\
\hline Calendar method(125) & 57 & 45.6 \\
\hline Withdrawal method(248) & 105 & 42.3 \\
\hline Lactational amenorrhea(120) & 49 & 40.8 \\
\hline
\end{tabular}

* $_{n}$ is the total no of study participant who have heard about the particular family planning method.

Table no. 8: shows that, out of the total participants who knew about calendar method, $45.6 \%$ of them had perception that, it was not a reliable method.

About $42.3 \%$ of the respondents who was aware of withdrawal method think it is not a reliable method.

Among the total respondents who knew about lactational amenorrhea, $40.8 \%$ of them had perception that, it was not a reliable method.

Table no.9: Side effects of condom as perceived by study participants

\begin{tabular}{|l|l|}
\hline Reason (n=151) & Frequency(Percentage) \\
\hline Itching & $70(46.3 \%)$ \\
\hline Loss of sexual pleasure & $12(7.9 \%)$ \\
\hline Allergy & $101(66.88 \%)$ \\
\hline
\end{tabular}

$*_{n}$ is the total no of study participants who reported that they are aware of side effects of condom.

Table no.9 reveals the perception of study participants related to condom. Among the total study participants, 151(32.1\%) of them believe there are side effects related to condom. Out of which $66.88 \%, 46.3 \%$ and $7.9 \%$ believe use of condom cause allergy, itching and loss of sexual pleasure respectively.

Table no.10: Side effects of male sterilization as perceived by study participants.

\begin{tabular}{|l|l|}
\hline Reason $\left(\mathbf{n}=\mathbf{1 2}^{*}\right)$ & Percentage \\
\hline Loss of libido & $3(25 \%)$ \\
\hline Difficult to do heavy works & $9(75 \%)$ \\
\hline
\end{tabular}

$*_{n}$ is the total no of study participants who reported that they are aware of side effects of male sterilization.

Table no.10 reveals the misconceptions related to male 
sterilization. Among the total study participants, 12 (2.7\%) of them believe there are side effects related to male sterilization. Out of which $75 \%$ (9) believe male sterilization causes reduced work out put and $25 \%$ (3) believe male sterilization will result in loss of libido.

\section{Table no.11: Knowledge about family planning methods}

\begin{tabular}{|l|l|l|}
\hline Grading & Frequency & Percentage \\
\hline Poor & 57 & 11.6 \\
\hline Average & 306 & 62.3 \\
\hline Good & 128 & 26.1 \\
\hline Total & 491 & 100.0 \\
\hline
\end{tabular}

Table no.11 shows that $62.3 \%$ had average knowledge about family planning method and $26.1 \%$ had good knowledge.

Knowledge questions were scored. Maximum score obtainable was 9 and minimum score was zero. Knowledge was graded as poor (0-3), average (4-6) and good (7-9).

\section{DISCUSSION}

\section{Socio-demographic profile}

The majority of the study participants were in the age group $35-39$ years $(22.4 \%)$ and $30-34$ years $(22 \%)$. The mean age of the study participants was $35.93 \pm 7.28$ years. This was almost similar to NFHS-3 report of Kerala. In their report, maximum number of reproductive age group women belongs to the age group 35- 39 years (15.9\%).(7) Among the study population, $98 \%$ of them belonged to Hindu religion. Only $4(1 \%)$ were there in both Muslim and Christian religion.

\section{Education}

In the present study, Majority $(35.2 \%)$ of the females is graduates, $30.1 \%$ of them had an education level up to intermediate school/diploma and almost all (97.4\%) had an educational qualification more than high school. None of the females were illiterates. NFHS-4 report of Kerala which showed that about $97.9 \%$ of women in the age group, 15-49 are literate and $72.2 \%$ of the women have completed 10 or more years of education. (8)

\section{Occupation}

In the present study, even though majority of females have education more than high school, $76 \%$ were unemployed. According to NFHS-3 Kerala only $29 \%$ of currently married women in the age group of 15 to 49 years are employed. (7)

\section{Socio economic status}

Based on updated B G Prasad classification (2016) of socioeconomic status, $37.9 \%$ of the study population belonged to upper middle class and $29.7 \%$ belonged to upper class. Very few, $0.6 \%$ of them belonged to lower class. This was similar to the finding in NFHS-3 Kerala, based on wealth index where $40 \%$ of rural households were in the highest wealth quintile and $6 \%$ in the lowest two wealth quintiles. (7)

\section{Family size}

In the present study, $57 \%$ belonged to a family size with less than or equal to four members. About $35 \%$ of the study population belonged to a family size with five to eight members and $8 \%$ belonged to a family size with 9 to 12 members. According to NFHS-3 Kerala, an average household in Kerala comprises of four members. (7)

\section{Knowledge}

The choice of selection of family planning method depends on the awareness about each method. There is no such thing called as an "ideal contraceptive method", that is why the concept called cafeteria approach came up. Under cafeteria approach we are offering the couples/ clients with all the available contraceptive method, so they can choose one method based on their need and demand. The knowledge regarding each method is very important so that, they can choose the right one according to their need. Findings of this study revealed that all are aware of at least one family planning method. Similarly a study conducted in Dharwad, India by Sunitha et al got the same result, all the respondents were aware of at least one method of contraception. (9) There are various studies showing different levels of awareness among contraceptive method. A study conducted in northern Kerala by Harpeet et al(10) revealed, the awareness level about contraception as $55.7 \%$, where as another study by Lavanya et al conducted in Andhra Pradesh, observed that $96.8 \%$ were aware of one or more of family planning methods.(11)

\section{Source of information}

Health workers especially ASHA workers and female health workers are the key persons, who can convey the knowledge and solve the queries about family planning methods to the people in the community. In this study the major source of information about family methods were from health workers $(72.1 \%)$. In a study done by Prachi et al in Sikkim, $73 \%$ of the respondents reported media as the main source of information. (12) A study by UrujJahan in Uttar Pradesh also reported, media as the main source of information.(13) A hospital based study conducted by Rozina et al in karachi also observed that media as the major source of information of contraceptives in $64 \%$ of women.(14) This study report is comparable with the study done by Mohammad et al at Chhattisgarh , they found health worker as the major source of information about family planning method.(15) Similar to it, Nirmala Jaget et al also found, the main source of information was through health workers followed by television.(16)

\section{The most known method}

The most known method of contraception among the respondents in this study was condom $95.7 \%$, followed by permanent method of family planning (female sterilization and male sterilization) which was $93.7 \%$ and $89.2 \%$, respectively. The least known method was injectables with $10.6 \%$. The findings were similar to the study done by Mohammad et al at Chhattisgarh. According to their study, the most known method was condom $(95.65 \%)$ followed by female sterilization $(85.09 \%)$ and intra uterine device (76.39\%).(15) Another study conducted by Lavanya et al, maximum awareness was for permanent method (tubectomy and vasectomy) of sterilization and none of them in their study was aware about injectables.(11)Also a study done in Uttar Pradesh by UrujJahan et al observed that OCPs (74.8\%) as the most commonly known method followed by condom $(68.8 \%)$ and intra uterine device (56.6\%). For them the least aware method was natural methods. (13)

\section{Temporary method of contraception}

Among the temporary methods of contraception, the most known method in ourtudy was condom $(95.7 \%)$ followed by oral contraceptive pills (85.7\%) and IUDs (83.5\%) and the least known method was injectables (10.6\%). Arjit et al in Lucknow found that the least aware method among temporary contraception as injectables $(1.1 \%)$ and the most aware method as OCPs (95.7\%) followed by copper T (46.8\%). (17) A study done by Arti Patel et al among postpartum women in Ahmedabad, observed that the most known method among temporary contraception was condom followed by copper $\mathrm{T}$ and injectables and the least known was oral contraceptive pills(18).

\section{Permanent method of contraception}

Among the permanent method of contraception the most aware method in our respondents is female sterilization $(93.7 \%)$ and that of male sterilization it is $89.2 \%$. Another study conducted by Mohammad Jawed et al in Chhattisgarh also showed same kind of result in his study, the most aware method among permanent method was female sterilization (97\%) followed by male sterilization (86\%). (15) Similarly study conducted in Trissur district, Kerala by Suchithra E.T et al (2015) observed that female sterilization was the most 
aware permanent method among the respondents compared to male sterilization. (19)

In contrast to this study, the report of study done by Prachi Renjhan et al in Sikkim revealed that the awareness of permanent method of contraception was the least and it was only $12 \%$.(12) A qualitative study conducted by Stella Babalola et al in Nigeria found that the percentage of respondents who were aware about female sterilization and male sterilization was only $23.9 \%$ and $7.9 \%$ respectively. (20)

Misconceptions related to family planning methods should be discouraged, especially male sterilization. It can affect an individual's decision to utilize family planning method. In the present study, among the total study participants, $12(2.7 \%)$ of them believe there are side effects related to male sterilization. Out of which $9(75 \%)$ believe male sterilization causes reduced work out put and $3(25 \%)$ believe that male sterilization will result in loss of libido. Similarly, respondents participated in a study done by Kishori Mahat et al in Nepal expressed fears that men who obtained a vasectomy makes one weak and impotent. (21)

Misconceptions about condom also exist. In this study, among the total study participants, 151 of them believe that there are side effects related to condom. Out of which $66.88 \%, 46.3 \%$ and $7.9 \%$ perceived that the use of condom cause loss of sexual pleasure, itching and allergy respectively. Lack of proper knowledge might be the reason for the misconceptions and fears related to family planning methods.

\section{Natural methods of contraception}

Knowledge about natural methods of contraception is quite low in the current study compared to temporary and permanent methods of contraception. Awareness about withdrawal method, lactational amenorrhea and calendar method were $50.5 \%, 24.4 \%$ and $25.5 \%$ respectively. Similarly Kanchan Lata et al from Bihar also found that, knowledge about withdrawal method and Calendar method were only $24.8 \%$ and $6.7 \%$, which was low compared to permanent and temporary methods. (22) The same result was got in a study done by Suchithra et al in Kerala, they observed the awareness of withdrawal was only $2 \%$ and that of calendar method it was $7.9 \%$ only. (23)

\section{CONCLUSION}

To conclude, the mean age of the study participants was 35.93 (SD 7.28) years and that of husbands was 43.49 (SD 9.83) years.

Out of 491 married females, $98.4 \%, 0.8 \%$ and $0.8 \%$ were Hindus, Muslims and Christians respectively. Majority (57\%) of them belongs to a family size of less than or equal to 4 members. About $37.9 \%$ of the study participants belong to upper middle class and $29.7 \%$ belongs to upper class.

In the present study, $97.4 \%$ of women had an educational qualification more than high school and most of the study participants (35.2\%) were graduates. Majority (71.5\%) of the women were housewives.

All of the study participants have heard of family planning and the main source of information was from Health workers. Majority (95.7\%) of them had heard of condom (95.7 percent) and the least heard method was injectables (10.6\%).

\section{Acknowledgements}

I express my deepest gratitude to the HOD, the whole staff and the interns of the Department of Community Medicine, ACME, Pariyaram.

\section{Declarations}

No Funding

No Conflict of interest

Ethical approval:Departmental Ethical clearance been taken.

\section{REFERENCES}

1. Census 2011 India [Internet]. [cited 2016 Sep 6]. Available from: http://www.census2011.co.in/

2. National Health Mission- [Internet]. copy right @ 2013 - NHM, government of india. 2013 [cited 2016 Sep 6]. Available from: http://nhm.gov.in/nrhmcomponents/rmnch-a/family-planning/background.html

3. K.Park.Park's textbook Preventive and social medicine.24th ed.M/s Banarsidas Bhanot;2017. Chapter 9,Demography and Family Planning;p- 525.

4. Rosliza AM, Majdah M. Male Participation and Sharing of Responsibility in Strengthening Family Planning Activities in Malaysia. Malaysian J Public Heal Med [Internet]. 2010 [cited 2017 Sep 7].;10(1):23-7. Available from: https://www.mjphm.org.my.

5. K. C. Zachariah. Models of Development and Demographic Change A Case Study of Kerala.Demography India. [Internet].1998 Jan. [cited 2016 Sep 8]27(1). 1998;27(June):71-89. Available from: womenstudies. in/ elib/ demography/dm models_of_development.pdf

6. Kerala National Family Health International Institute for Population Sciences Deonar, Mumbai -400 088 Ministry of Health and Family Welfare Government of India. 2005 [cited $2017 \mathrm{Sep} 15]$; Available from: http:// rchiips. org/ nfhs/ NFHS-3 Data/ke_state_report_for_website.pdf

7. International Institute for Population Sciences, Macro International. National Family Health Survey (NFHS-3), India, 2005-06: Kerala. [Internet].] 2008 [cited 2017 Nov 2]. Available from: https:// dhsprogram. com/ pubs/ pdf/ FRIND3/ FRIND3-Voll[Oct-17-2008].pdf

8. National Family Health Survey(NFHS - 4): Kerala Fact Sheet. Ministry of Health and Family Welfare Government of India.[Internet]. [cited 2017 Sep 8]; Available from:http://rchiips.org/NFHS/pdf/NFHS4/KL_FactSheet.pdf

9. T.H. Sunita, Desai RM. Knowledge, attitude and practice of contraception among women attending a tertiary care hospital in India. Int J Reprod Contracept Int J Reprod Contracept Obs Gynecol [Internet]. 2013 [cited 2017 Oct 22];22(22):172-6. Availablefrom:http://dx doi.org/10.5455/2320-1770 ijrcog20130612

10. Dr. Harpreet Kaurl, Dr. Parveen Mohan2, Dr. Nayana Pathak3, Dr. Apurv Manocha4 DA. Knowledge, Attitude, Practices and Behavior of Women Towards Contraceptive Use.Indian Journal of Obstetrics and Gynecology Research 2014;1(1):1-6. [Internet].] 2008 [cited 2014 Nov 2]. Available from: https:// www. innovative publication. com/ admin/ uploaded files/ IJOGR\% 20Vol\% 201(1)\%2025-30.pdf.

11. Sarella LK, Prasanna NSL. A study on contraceptive knowledge, attitude and practice among reproductive age group women in a tertiary institute. Int Journalof Res Heal Sci [Internet]. 2014;10(2):577-80. Available from: http:// ijrhs. com/ admin/ download newsroom. php? fname $=$ MjUuSOFQXOZ QXzIlOC 5wZGY $=$

12. Renjhen P, Kumar A, Pattanshetty S, Sagir A, Samarasinghe CM. A study on knowledge, attitude and practice of contraception among college students in Sikkim, India. J Turkish Ger Gynecol Assoc [Internet]. 2010 [cited 2017 Oct 3];11(2):78-81. Available from:http://www.ncbi.nlm.nih.gov/pubmed/24591903

13. Jahan U, Verma K, Gupta S, Gupta R. Awareness, attitude and practice of family planning methods in a tertiary care hospital, Uttar Pradesh, India. Int J Reprod Contraception, Obstet Gynecol Int J Reprod Contracept Obs Gynecol [Internet]. 2017 [cited2017 Sep 30];66(22):500-6. Available from:www.ijrcog.org

14. Mustafa R, Afreen U, Hashmi H a. Contraceptive knowledge, attitude and practice among rural women. J Coll Physicians Surgeons Pak. 2008;18(9):542-5. [Internet]. ] 2008 [cited 2014 Nov 2]. Available from: https://www.ncbi.nlm.nih.gov/pubmed/18803890

15. Mohammad Jawed Quereishi, Ann Kavitha Mathew, Ashish Sinha. Knowledge, attitude and practice of family planning methods among the rural females of Bagbahara block Mahasamund distric $t$ in Chhattishgarh State, India. Glob J Med public Heal [Internet]. 2017 [cited 2017 Oct 3];6:1-7. Available from: http://www.gjmedph.com/uploads/O2-Vo6No2.pdf

16. Lakkawar N, L JR. Assessment of knowledge and practice of contraceptives among women in reproductive age attending out patient department at a sub-urban centre in Pondicherry, India. Indian J Basic Appl Med Res [Internet]. 2014 [cited 2017 Sep 30];4(1):196-209. Available from: http:// ijbamr.com/pdf/December 2014 196-209.pdf

17. Kumar Arjit, Bhardwaj P, Srivastava JP, Gupta P. A study on family planning practices and methods among women of urban slums of lucknow city [Internet]. Vol. 23, Indian Journal of Community Health. Indian Association of Preventive and Social Medicine Uttar Pradesh and Uttarakhand (IAPSMUPUK) State Chapter; 2011 [cited 2017 Sep 30]. 75-77 p. Available from: http:// www. iapsmupuk. org/journal/index.php/IJCH/article/view/17/30

18. Patel A, Pawani C, Patel R. Awareness and acceptance of contraceptive methods among post-partum patients. Int J Reprod Contracept Int J Reprod Contracept Obs Gynecol Int J Reprod Contracept Obs Gynecol Int J Reprod Contracept Obstet Gynecol [Internet].2016 [cited2017 Oct23];555(5). Available from:www.ijrcog.org

19. Suchithra E., Sujina CM. Current Practice and Determinants of Family Planning Methods among Married Females in the Reproductive Age Group (15-49yrs) in a Rural Setting, Kerala. Indian J Forensic Community Med [Internet].2016. [cited $2017 \mathrm{Sep} 30] ; 3(1): 13$. Available from: http:// www. indianjournals. com/ ijor. aspx target $=$ ijor: ijfcm \& volume $=3 \&$ issue $=1 \&$ article $=004$

20. Babalola S, John N, Hopkins J. The RESPOND Project Study Series: Contributions to Global Knowledge Factors Underlying the Use of LongActing and Permanent Family Planning Methods in Nigeria: A Qualitative Study. 2012 [cited 2017 Oct 23]; Available from: http://www.respond-project. org/archive/files/4/4.1/4.1.3/Study5-2012-Factors-Underlining.pdf

21. Mahat K, Pacheun O,Taechaboonsermsak P, Marg L. Intention to Accept Vasectomy among Married Men in Kathmandu, Nepal. Asia J Public Heal Asia J Public Heal [Internet]. 2010 [cited 2017 Nov 17];1(11):8-14. Available from: http:// ns2. ph mahidol.ac.th/phklb/knowledgefiles/4_Intention to AcceptVasectomy.pdf

22. Kanchan Lata I,Kumar Barman S,RamR,Mukherjee S, Kumar Ram A,Author C,et al. www.gjmedph.org Prevalence and determinants of unmet need for family planning in Kishanganj district. Glob J Med Public Heal [Internet]. [cited 2017 Oct 3];1(4).Available from:http://www.gimedph.com/ uploads/o6-VolNo4.pdf

23. Suchithra E., Sujina CM. Current Practice and Determinants of Family Planning Methods among Married Females in the Reproductive Age Group (15-49yrs) in a Rural Setting, Kerala. Indian J Forensic Community Med [Internet].2016.[cited 2017 Sep 30];3(1):13. Available from:

24. http:// www. indianjournals. com/ ijor. aspx? target= ijor: ijfcm\& volume= 3\&issue $=1 \&$ article $=004$ 